\title{
Revealing the Wage Phillips Curve on the Relationship Between Wage Growth and Unemployment Rate
}

\author{
Mingyang Jiang ${ }^{1, \dagger}$, Mian Wang ${ }^{2, *}{ }^{*}$, Xinkai Zhuo ${ }^{3, \dagger}$, Junyi Zou ${ }^{4, \dagger}$ \\ ${ }^{1}$ Soochow Academy, Suzhou High School of Jiangsu Province, Suzhou, 215000, China \\ ${ }^{2}$ Soochow Academy, Suzhou High School of Jiangsu Province, Suzhou, 215000, China \\ ${ }^{3}$ Dalton, The Affiliated High School of Peking University, Beijing, 100080, China \\ ${ }^{4}$ Beijing, Royal School, Beijing, 10000, China \\ *Corresponding author. Email: zhuoxinkai@i.pkuschool.edu.cn \\ These authors contributed equally
}

\begin{abstract}
The Phillips Curve is a well-known concept in macroeconomics, where the relationship between the unemployment rate and wage growth is a dominant element. The purpose of this study was to explore the failure of revealing normal relationship between wage growth and unemployment in 2001 based on the wage Phillips curve reveal. Specifically, we further developed some previous theories by analysing the case of the Great Depression in 2001.The research combined qualitative and quantitative methods as the approach of the case study. This paper addressed the question that why didn't the wage Phillips curve reveal a normal relationship between wage growth and unemployment in 2001 according to the three aspects mentioned above. Furthermore, the research provided several new aspects in the study of wage Phillips's curve as well as the causality led to low wage growth in 2001. Several implications like the monetary policiesand solutions combined with factors like the shocks on labor markets or difference in wage levels were discussed within the paper. These results shed light on the essence of the depression in 2001, make a forecast on the following years which probably will face the same situation and help have better preparations.
\end{abstract}

Keywords: Wage Philips curve, Wage growth, Unemployment rate, 2001, U.S.

\section{INTRODUCTION}

After World War II, to recover society and economic activity, the brainchild of U.S. Secretary of State George C. Marshall set a policy called Marshall plan named by his name, and also known as European Recovery Program. It aims to reconstruct cities, industries, and infrastructure that damaged during the war. In addition, it removed trade barriers between European neighbours and fostered commerce between those countries and the United States [1]. Based on the Marshall Plan and other economic assistance programs, the United States exported many funds, technology, and job opportunities to the West, especially the Western European countries, to help the Western countries recover their national strength. Meanwhile, the emergence of the third world countries and the United Nations, and other global organizations that protect the world economy have led to a relatively peaceful environment. The coverage of research continues before the COVID-19 because the economy and employment had faced a huge crisis, which is even still in processing. It involves several aspects to consider rather than the normal factors. This paper does not contain the period of COVID-19 to eliminate the uncontrollable and undiscovered factors to influence the validity of the study. According to the period between post-World War II and pre-coronavirus pandemic, the society trended to be stable with keeping rise tendency of the employment rate in the U.S. However, nowadays, economics has realized that labour wages have not shown a significant increase through the increase in the employment rate in the United States as a common understanding of Macroeconomics.

This research uses qualitative method, especially case studies, three great recessions, to analyse the relationships between the wage growth and the low unemployment rate in the U.S. Especially the functions of the domestic economy and global economy on the labour market, the alternative workers, economic globalization affect the world and the unbalanced distribution of income of the new and the old in the labour market. 


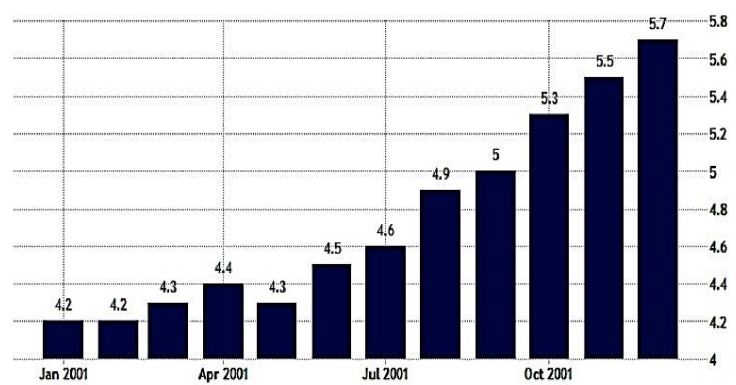

Figure 1The unemployment rate of the United State in $2001[2]$

First of all, we can see that the unemployment rate trend in 2001 shows a general upward trend, as illustrated in Fig. 1.

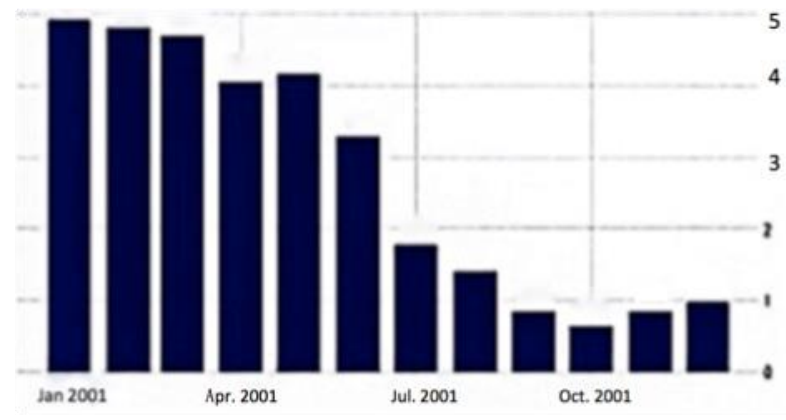

Figure 2 The wage growth in the United States in 2001 [3]

Subsequently, Fig. 2 depicts that wage growth in the United States has generally been declining throughout 2001. It should be noted that the decline was particularly pronounced from June to July, and the wage growth remained at a low level in the following months, which tally well with the Phillips curve.

To further explain, in the United States, wage growth refers to the annual change in wages and salaries paid by the government, manufacturing, and service industries. The unemployment rate is the percentage of the labour force without a job. Previously, it was assumed that wage growth was inversely related to unemployment, with the lower the unemployment rate, the higher the wage growth. After World War II, however, a curious phenomenon occurred. Low unemployment did not lead to meaningful wage growth. Contemporarily, there has been growing interest in wage growth, one of the classic indicators of residents' lives. Harriet and Mark C. in 1997 examined wage growth among immigrants and natives and examined why the former saw higher wage growth than the latter[4]. Stephen G. and Melissa found differences between employer-specific wages, tenure, and wage increases in 1997[5]. Alit Munasinghe studied the role of wage growth in forecasting turnover in 2000 [6]. Fatehin and David used the theory of rapid economic assimilation to determine the reason for the increase in high-wage jobs in 2016[7]. In 2017, Mary C. and Bart studied the phenomenon that aggregate real wages exhibit less pro-cyclicality than most models predict [8].
Different from previous studies, this paper focuses on the Phillips curve and tries to analyse the relationship between wage growth, unemployment rate, and even the two.

Overall, this research paper discusses the reasons that Wage Phillips curve did not reveal the normal relationship between wage growth and unemployment in 2001. To address this issue, this study summarizes the original Phillips curve through literature review, and also uses the new Keynesian model, marginal productivity compensation theory, Marxist wage theory, collective bargaining wage theory, and other theories. These theories form the basis of the research, and these ideas are representative of previous research on unemployment and wage growth. In addition, the past situation in the United States is the dominant thesis of the study. The analysis focused on this exact object. In addition, the core of the research method is the qualitative method. Based on a large number of data collection and data analysis, this paper comprehensively explains and clarifies the research issues through the study of specific cases of the 2001 Great Economic Recession and other data. As mentioned in the previous paragraph, the main motivation for this thesis is that around 2001, the Phillips curve "failed" a little and people's interest in wage growth increased. Then, all the methods mentioned above are designed to investigate the relationship between wage growth and unemployment by using the Phillips curve.

Specifically, this study includes several aspects: the developed economy and the large labour force in the domestic market make the future labour force have less impact on wages; the more intense competition brought by economic globalization makes employers hire labour force at relatively low wages; young (mid-wage) workers have replaced mature and well-paid workers to make up for the wage gains from America's low unemployment rate; low unemployment is influenced by more factors than wage growth. We will further develop the government's macro-control and intervention system. This process gradually clarified the statement of the paper and put forward some reasonable suggestions based on the conclusion, which explain the anomalies around 2001 in these terms.

This research uses qualitative method, especially data analysis to investigate the relationships between the wage growth and the low unemployment rate in the U.S in 2001 great recessions. Especially the functions of the domestic economy and global economy on the labour market, wage in different occupations, the alternative workers, economic globalization affect the world and the unbalanced distribution of income of the new and the old in the labour market. These aspects explain the abnormal phenomena. 


\section{LITERATURE REVIEW}

Essentially there are two keywords, unemployment rate, and wage growth, in this paper. An economic model called the Phillips curve best illustrates their relationship. In 1958, William Phillips, a New Zealand economist, wrote a paper that explored the relationship between Unemployment and the Rate of Change of Money Wage Rates in the United Kingdom between 1861-1957 [9]. In this paper, Phillips concluded an inverse relationship between money wage changes and unemployment in the British economy. This is the first appearance of the legible relationship, and the curve that reveals this relationship won the name of the Phillips curve. It's worth mentioning that Irving Fisher, an American economist, had noted this similar relationship, but that paper weighed more on price changes instead of wage changes. In the years following Phillips's 1958 paper, many economists in the advanced industrial countries offered constructive contributions, e.g., the study of the slope of this linear inverse relationship and how monetary policy or fiscal policy can shift the Phillips curve. Some economists also queried that the Phillips curve only worked in the short run, with plenty of research supported. Currently, it seems to be impossible to find logical loopholes of the Phillips curve, i.e., most opponents try to find exceptions and make new claims based on those special cases. Moreover, certainly, the Phillips curve model is mostly applied in economics, while sometimes it can also satisfy political needs. Some monetary policies, e.g., are published to balance the inflation rate or wage growth rate and the unemployment rate. The Phillips curve is a reliable source to tell the Federal government when to implement the policies.

The next few pages will be devoted to the three kinds of Phillips curves that have been developed.

The first Phillips curve shows the relationship between unemployment and the rate of change in money wages. This is the economist Phillips first proposed in 1958 by Phillips. It takes the form of a curve with a negative slope sloping from the bottom right to the top left on a coordinate chart with the unemployment rate as the horizontal axis and the rate of change of money wages as the vertical axis. It shows that the unemployment rate and the change rate of money wages are opposite to each other, i.e., the negative correlation[9].

The second Phillips curve depicts the relationship between unemployment and the rate of the price increase. It was first proposed by economists Samuelson and Solow in 1960.Samuelson and Solow replaced the rate of change in money wages in the original Phillips curve with the rate of price increases[10]. This substitution is achieved through a hypothesis. The assumption is that the product price is formed according to the "average labour cost fixed value method", i.e., the price per unit of product is formed by the average labour cost plus a fixed proportion of other costs and profits. In other word, changes in prices are related only to changes in money wages. This Phillips curve is the same as the first Phillips curve, except that the vertical axis is changed to the rate of price increase. This curve indicates that the unemployment rate and the price increase rate of the two are also the opposite of the corresponding change[9].

The third Phillips curve shows the relationship between the rate of economic growth and the rate of the price increase. This Phillips curve replaces the unemployment rate in the second Phillips curve with the rate of economic growth, through Okun's law. Economist Okun put forward in 1962 that the unemployment rate and the economic growth rate have the opposite corresponding change relationship[11]. In the study of this relationship, the economic growth rate indicator is often not used directly, but "the deviation of the real economic growth rate from the potential economic growth rate" or "the deviation of the real output level from the potential output level". This "deviation" indicates a certain period of social total supply and demand gap and price pressure. The actual economic growth rate indicates the output growth determined by the total social demand in a certain period, while the potential economic growth rate indicates the total supply provided by the human, material, financial and other resources in a certain period and at a certain technical level $[9,12]$.

Robert J. Gordon of Northwestern University, for example, has analysed the Phillips curve to arrive at what he calls the triangle model, in which the actual inflation rate is determined by the sum of two measures1. Demandpull or short-term Phillips's curve inflation,2. Cost-push or supply shocks, and built-in inflation. He would not be able to endure long-term expectations $[9,13]$.

After William Phillips presented the Phillips curve that revealed an inverse relationship between unemployment and money wage changes, a group of economists headed by Milton Friedman challenged that the Phillips curve relationship was only a short-run phenomenon. This was based on Samuelsson and Solow who wrote The discussion focus on short-run terms, which means the things might happen in the next few years. It is wrong to think that related obtainable price and unemployment behavior will retain the identical shape in long-run terms. The potential policy in next few years might influence the shift definitely[10]. In Friedman's opinion, he believed that over the long run there is no trade-off between inflation and unemployment. Therefore, the curve should be a vertical line instead of the linear inverse relationship revealed by Phillips' Phillips curve. What's more, he then correctly predicted that in the 1973-75 recession, both inflation and unemployment would increase [14]. Actually, in the 1970s, many countries truly experienced high inflation with high employment, known as stagflation, and contradicted Phillips's curve. This finding gives this 
paper confidence that the Phillips curve doesn't fit all situations, since this paper is designed to explain a phenomenon, which is exactly against the Phillips curve. It also inspires this paper that those great recessions will be inevitable periods if this paper wants to analyse the reasons behind the extraordinary relationship between unemployment and wage growth. There are other explanations for the possibility of the inconsistency of the Phillips curve. Mary C. Daly and others concluded that decreasing nominal wage contributes to the unemployment gap and wage growth diverse from the normal relationship. the discrepancy was rectified and the wage Phillips curve return to normal, while the economy recovers gradually [15]. Put 'downward nominal wage rigidity' together with 'sticky wage', with the complement of a view held by Edmund Phelps that Only rational workers can react to real wages without be confused by money illusion [16], factors that affect the wage growth side can be critical clues to explain the topic question.

As stated above, this paper has combined the Diamond-Mortensen-Pissarides model, from quantitative economics, and the triangle model obtained by using the curve to understand the relationship between the unemployment rate and real object inflation. In the meantime, this paper finds a counterargument that the Phillips curve is not strictly linear, as implied by the standard model of the labour market. It also explains the two stages in which the clockwise cycle of the Wage Phillips curve occurs. Some scholars have analysed the factors that affect the curve. For the deeper and wider fields to be studied in the future, e.g., exploring the objective factors related to the unemployment rate, trying to establish new models, and analysing the dependent variable changes caused by the independent variable unemployment rate or related variables, etc.

\section{METHODOLOGY}

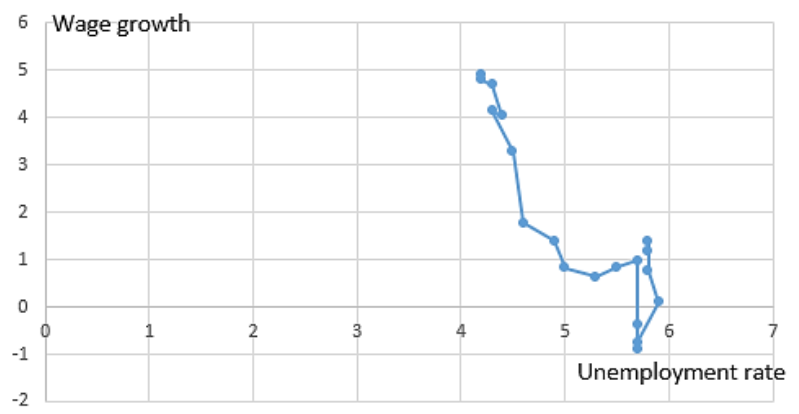

Figure 3 Wage Philips curve in 2001 in U.S.

\subsection{Analysis of the wage Phillips curve in the United States}

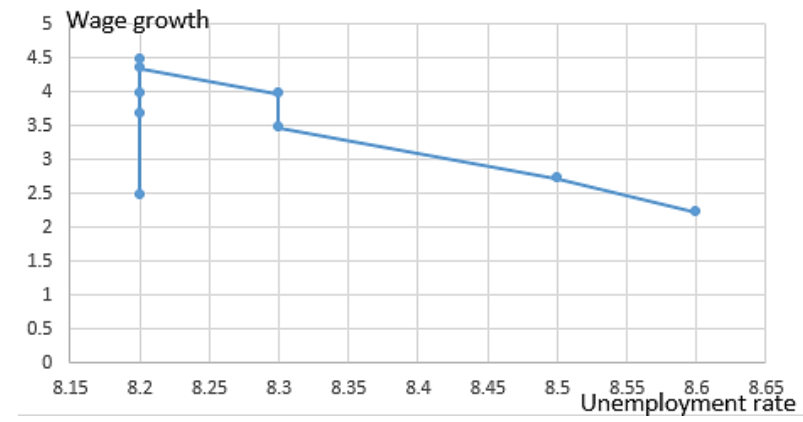

Figure 4 Wage Philips curve in 2011 in U.S.

To investigate the relevance between the US unemployment rate and wage growth, this paper used statistics from tradingeconomics.com from 2001 to 2002 by Microsoft being. Then it drew a Philips curve the horizontal axis(x-axis) represented to unemployment rate while the vertical axis(y-axis) represented wage growth as illustrated in Figure 3. By repeating the previous action to find data of the US unemployment rate and wage growth from 2011 September to 2012 July as Figure 4, this paper compared two of thosefigures with the Phillips curve theory.

According to the wage Philips curve, the unemployment rate decrease as wage growth increase. However, in Figure 3, the unemployment decreased from 5.9 to 5.7 with wage growth decreased from 0.09 to -0.76 , then -0.91 . Hence, the low unemployment in that time did not deliver wage growth in that time interval.

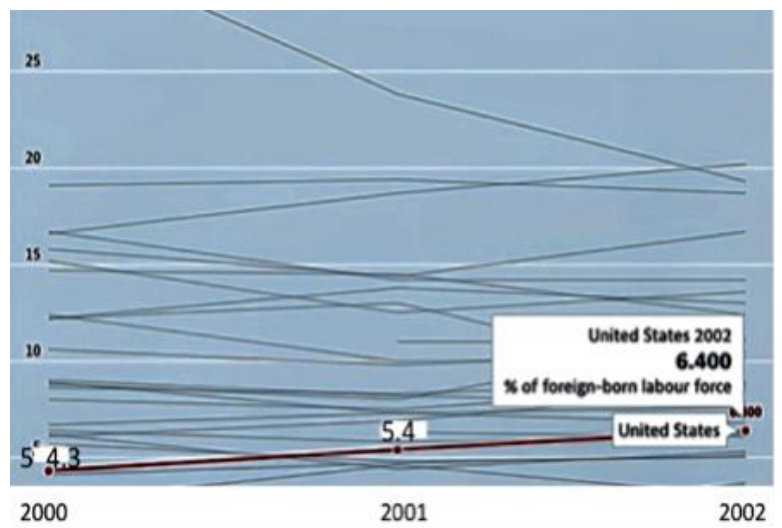

Figure 5 Foreign-born unemployment in 2000-2002[17]

Figure 5 depicted an obvious trend that a lower unemployment rate contributed to higher wage growth in the reverse movement trend. It abided by the wage Phillips curve theory as a formal Phillips curve.

\subsection{Hypothesis of the impact of foreign-born labours}

One hypothesis this paper makes is that foreign-born labours will shock the structure of the labour market 


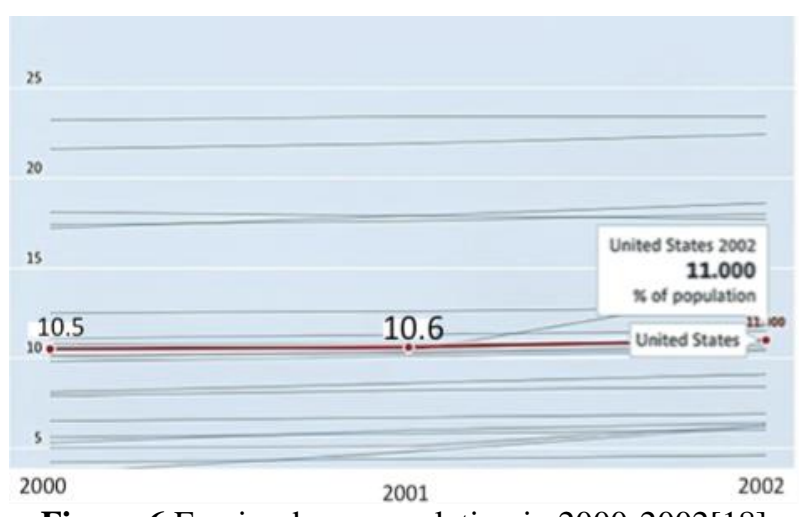

Figure 6 Foreign-born population in 2000-2002[18]

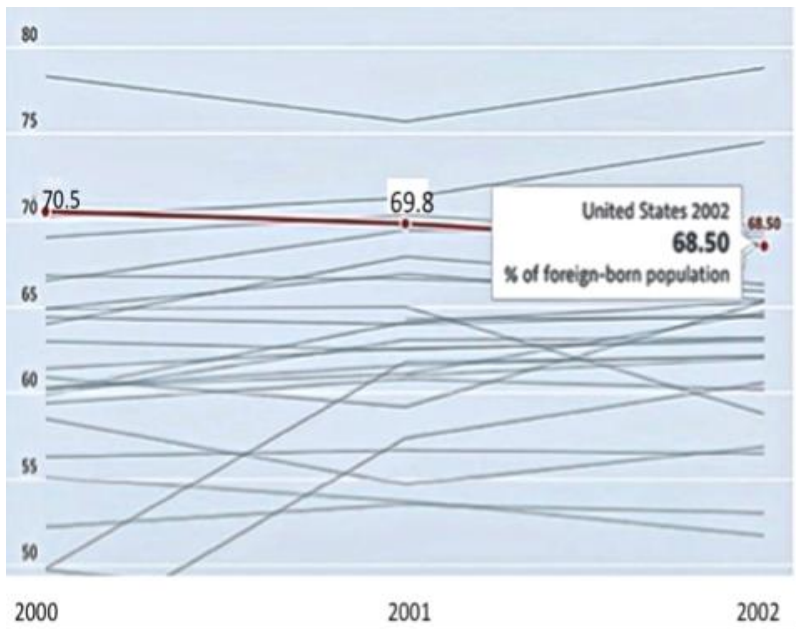

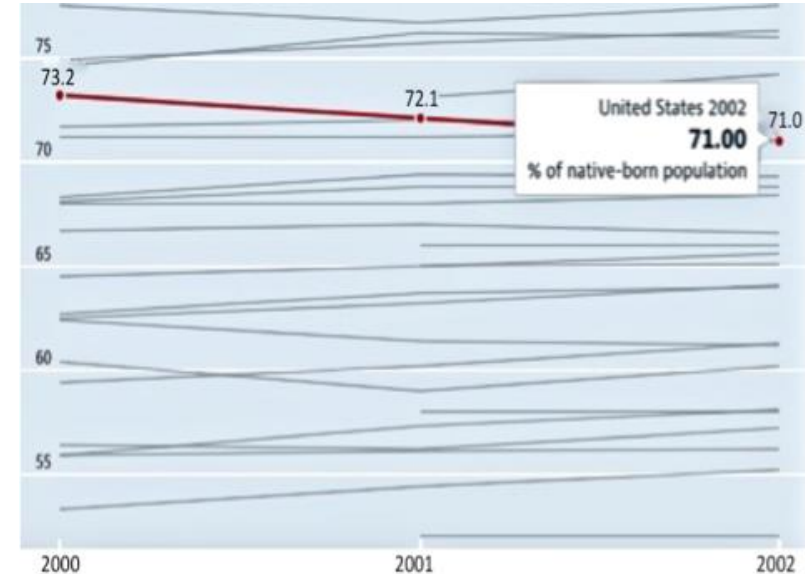

Figure 8 Native-born employment in 2000-2002[20]

As seen in Figs.6 and 7, in 2001foreign-born population was $10.6 \%$ of the total population, with a $69.8 \%$ employment rate of foreign-born population. The actual employment rate of the total population should be $10.6 \%$ multiplies $69.8 \%$, which is $7.4 \%$.

In Figure 8 , the native-born employment rate was $72.1 \%$ of native-born population, $64.5 \%$ of the total population. In comparison, the employment of the foreign-born labours exceeded $10 \%$ of that of the nativeborn labours. Thus, the foreign-born labours could to change the labour market.

Figure 7 Foreign-born employment in 2000-2002 [19]

Table 1 Employment status of the civilian noninstitutional population by educational attainment, sex, race, and Hispanic origin in 2001-2002 [21]

\begin{tabular}{|c|c|c|c|c|c|c|}
\hline \multirow{2}{*}{ Educational attainment } & \multicolumn{2}{|c|}{ Total } & \multicolumn{2}{|c|}{ Men } & \multicolumn{2}{|c|}{ Women } \\
\hline & 2001 & 2002 & 2001 & 2002 & 2001 & 2002 \\
\hline \multicolumn{7}{|l|}{ TOTAL } \\
\hline Civilian noninstitutional population $\quad . .$. & 180,287 & 182,228 & 85,813 & 86,813 & 94,474 & 95,415 \\
\hline $\begin{array}{l}\text { Civilian labor force } \\
\text { Unemployed }\end{array}$ & $\begin{array}{r}121,275 \\
4,429\end{array}$ & $\begin{array}{r}122,497 \\
5,695\end{array}$ & $\begin{array}{r}65,176 \\
2,351\end{array}$ & $\begin{array}{l}65,861 \\
3,105\end{array}$ & $\begin{array}{l}56,099 \\
2,078\end{array}$ & $\begin{array}{l}56,636 \\
2,590\end{array}$ \\
\hline $\begin{array}{l}\text { Unemployment rate } \\
\text { Less than a high school diploma............... }\end{array}$ & 3.7 & 4.6 & 3.6 & 4.7 & 3.7 & 4.6 \\
\hline 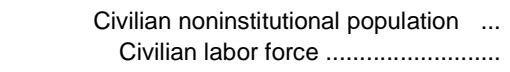 & $\begin{array}{l}28,602 \\
12,581\end{array}$ & $\begin{array}{l}28,382 \\
12,599\end{array}$ & $\begin{array}{r}13,618 \\
7,680\end{array}$ & $\begin{array}{l}13,700 \\
7,833\end{array}$ & $\begin{array}{l}14,984 \\
4,901\end{array}$ & $\begin{array}{r}14,682 \\
4,766\end{array}$ \\
\hline $\begin{array}{c}\text { Unemployed } \\
\text { Unemployment rate }\end{array}$ & $\begin{array}{r}912 \\
7.2\end{array}$ & $\begin{array}{r}1,064 \\
8.4\end{array}$ & $\begin{array}{r}491 \\
6.4\end{array}$ & $\begin{array}{r}613 \\
7.8\end{array}$ & $\begin{array}{l}421 \\
8.6\end{array}$ & $\begin{array}{r}451 \\
9.5\end{array}$ \\
\hline $\begin{array}{l}\text { Civilian noninstitutional population } \ldots \\
\quad \text { Civilian labor force } \ldots \ldots \ldots \ldots \ldots \ldots \ldots \ldots \ldots \ldots\end{array}$ & $\begin{array}{l}58,621 \\
37,644\end{array}$ & $\begin{array}{l}58,861 \\
37,764\end{array}$ & $\begin{array}{l}27,018 \\
20,132\end{array}$ & $\begin{array}{l}27,156 \\
20,241\end{array}$ & $\begin{array}{l}31,603 \\
17,512\end{array}$ & $\begin{array}{l}31,704 \\
17,523\end{array}$ \\
\hline $\begin{array}{l}\text { Unemployed } \\
\text { Unemployment rate }\end{array}$ & $\begin{array}{r}1,566 \\
4.2\end{array}$ & $\begin{array}{r}1,985 \\
5.3\end{array}$ & $\begin{array}{r}858 \\
4.3\end{array}$ & $\begin{array}{r}1,087 \\
5.4\end{array}$ & $\begin{array}{l}708 \\
4.0\end{array}$ & $\begin{array}{r}898 \\
5.1\end{array}$ \\
\hline 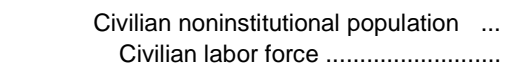 & $\begin{array}{l}45,709 \\
33,696\end{array}$ & $\begin{array}{l}45,968 \\
33,616\end{array}$ & $\begin{array}{l}20,858 \\
16,857\end{array}$ & $\begin{array}{l}20,963 \\
16,802\end{array}$ & $\begin{array}{l}24,851 \\
16,839\end{array}$ & $\begin{array}{l}25,005 \\
16,814\end{array}$ \\
\hline $\begin{array}{l}\text { Unemployed } \\
\text { Unemployment rate } \\
\text { Some college, no degree }\end{array}$ & $\begin{array}{r}1,110 \\
3.3\end{array}$ & $\begin{array}{r}1,523 \\
4.5\end{array}$ & $\begin{array}{r}555 \\
3.3\end{array}$ & $\begin{array}{r}770 \\
4.6\end{array}$ & $\begin{array}{l}555 \\
3.3\end{array}$ & $\begin{array}{r}752 \\
4.5\end{array}$ \\
\hline $\begin{array}{l}\text { Civilian noninstitutional population } \\
\quad \text { Civilian labor force }\end{array}$ & $\begin{array}{l}30,955 \\
22,238\end{array}$ & $\begin{array}{l}30,890 \\
21,990\end{array}$ & $\begin{array}{l}14,531 \\
11,466\end{array}$ & $\begin{array}{l}14,493 \\
11,346\end{array}$ & $\begin{array}{l}16,424 \\
10,772\end{array}$ & $\begin{array}{l}16,397 \\
10,644\end{array}$ \\
\hline $\begin{array}{l}\text { Unemployed } \\
\text { Unemployment rate } \\
\text { Associate degree }\end{array}$ & $\begin{array}{r}779 \\
3.5\end{array}$ & $\begin{array}{r}1,062 \\
4.8\end{array}$ & $\begin{array}{r}390 \\
3.4\end{array}$ & $\begin{array}{r}536 \\
4.7\end{array}$ & $\begin{array}{l}390 \\
3.6\end{array}$ & $\begin{array}{r}527 \\
4.9\end{array}$ \\
\hline
\end{tabular}




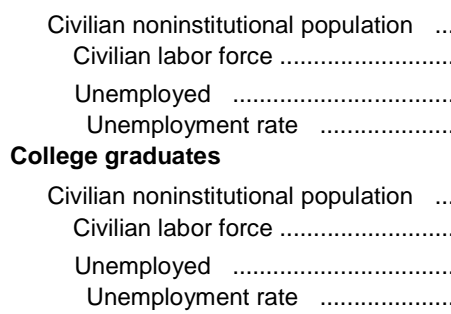

\begin{tabular}{r|}
14,755 \\
11,458 \\
331 \\
2.9 \\
\\
47,354 \\
37,354 \\
841 \\
2.3
\end{tabular}

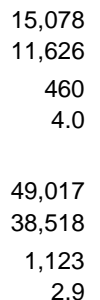

\begin{tabular}{r|}
6,328 \\
5,391 \\
165 \\
3.1 \\
\\
24,318 \\
20,508 \\
447 \\
2.2
\end{tabular}

\begin{tabular}{|c|c|}
\hline 6,470 & 8,427 \\
\hline 5,456 & 6,067 \\
\hline 235 & 166 \\
\hline 4.3 & 2.7 \\
\hline 24,994 & 23,036 \\
\hline 20,985 & 16,847 \\
\hline 635 & 394 \\
\hline 3.0 & 2.3 \\
\hline
\end{tabular}

Moreover, in Table 1, if the civilian has a higher degree, the unemployment rate will be lower. On this basis, if one has a higher educational level, he is harder to be substituted and can gain a relatively higher wage level. As a result, a considerable amount of the foreignborn labours took up relatively lower-paying occupations like operators, fabricators, and labourers, driving previous native-born labours to nearby regions. This would significantly increase the unemployment rate, with a relatively low impact on wage growth, for those were mostly low-wage occupations.

\subsection{Hypothesis of the wage levels of different labours}

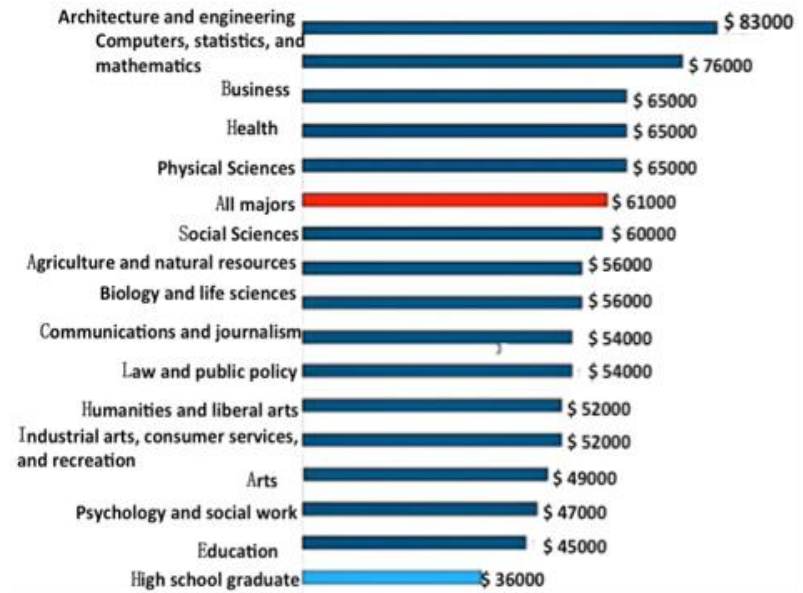

Figure 9 Median annual wages of college-educated workers by major supergroup [22]

From the above Figure 9, it is not difficult to conclude that the factors affecting the wages of workers are education and the requirements of different industries, e.g., construction, engineering, computer statistics and mathematics, and economics. Workers with a college degree can earn higher salaries on average than those with a high school degree.

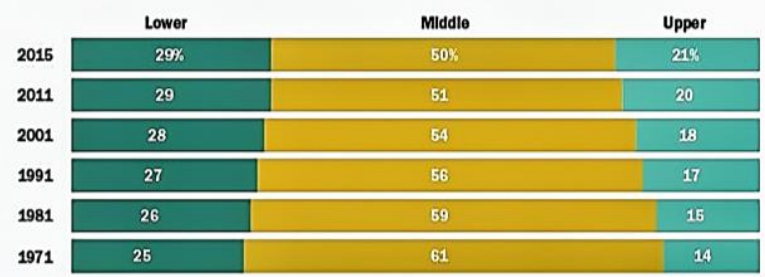

Figure 10 Share of U.S. adults by income tier [23]

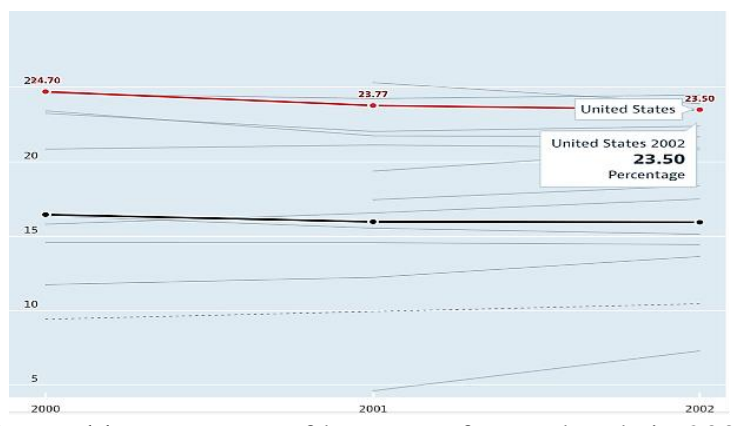

Figure 11 Percentage of low pay of wage levels in 20002002[24]

One more thing to say, from "Population Trends over the Years -- Statistics on the trend of the total number of young adults and gradually entering the working Age (15 to 64 years old) in the United States over the years (19592020)", one can see that the market will expand and there will be more jobs. However, according to Figure 11, the number of workers with high salaries and low salaries will increase in a certain relative proportion. Apart from the impact of some unexpected events, there will not be a sudden sharp increase or decline in workers' wages. Meanwhile, there will be a relative increase in basic living costs. Therefore, the increase and the consumption will correspond to the counterbalance. In this case, the average wage will not increase significantly even if the population base increases, the number of jobs increases, and the number of people in employment increases. In addition, it can be seen from Figs.10and 11that the middle- and lowincome people have always accounted for a large proportion in the country, and the well-paid employees have always been in the minority. The increase in average wages must be driven by the workers who account for about $20 \%$ of the population.

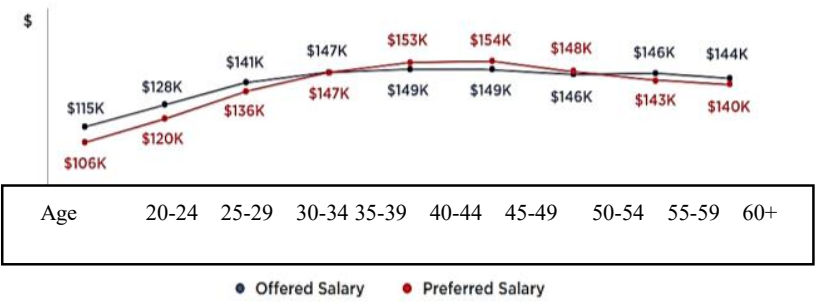

Figure 12 Average preferred salaries and salaries offered by age in the U.S.

From Figure 12, older workers (more experienced workers) are paid more on average than younger people 
up until the age of 50. This involves young, middleincome workers, as mentioned in the paper.

\section{RESULTS}

By comparing the wage Phillips curve in 2001 with the wage Philips curve in 2011, the curve that obeys the Philips curve theory, indicating that reduced unemployment rate did not deliver a prominent increasing trend in wage growth in 2001.

Through several figures from OECD Data, this paper finds the direct factor of the extraordinary relationship between unemployment and wage growth is that the replacement of the foreign-born labours, which is consistent with the hypothesis proposed previously. Based on data analysis in different figures, this paper also finds the educational level and unemployment rate are inversely related, which provides a new aspect in the study of wage Phillips's curve.

According to above chart analysis, the impact of labour element can be subdivided into, degree, different careers, market capacity, work experience, etc. When it comes to these factors change, the unemployment rate will rise or fall, but generally will not have the too big fluctuations. Since these variables already appear in the process of social development, there has been a certain development trend.

\section{DISCUSSION}

This paper generally made a response to the question of why the wage Phillips curve didn't reveal a normal relationship between wage growth and unemployment in 2001. Through several quantitative studies like data analysis and image drawing, this paper successfully found some factors related to the abnormal wage Phillips curve, which are the displacement from the foreign-born labours and the great portion of middle and low wage labours in the labour market. These factors reduce the impact of unemployment on wage growth. This finding effectively suggests that the wage Phillips curve is not suitable in all known situations, which admonishes some papers that entirely accept the concepts of the wage Phillips curve. Additionally, it also offers some new aspects on the studies of the wage Phillips curve and creates a path for latter economists to excavate deeper and more conclusive findings, greatly contribute to the development of the wage Phillips curve.

Some previous studies about the wage Phillips curve started at William Phillips, a New Zealand economist

who defined the concept of the curve that there is an inverse relationship between the unemployment rate and the wage change [14]. According to some data from the Bureau of Labour Statistics, this paper created an image of the wage Phillips curve in 2001 and found that the relationship it revealed was more likely to be irregular instead of the inverse shape. This outcome challenged the conventional wage Phillips curve with indubitable evidence. Similar to Milton Friedman's prediction that both inflation and unemployment would increase in the 1973-75 recessions [14], this paper was based on the background of the 2001 recession. It seems that the wage Phillips curve is more likely to be disproved in a specific period like recessions or some other situations. Moreover, some terms like stagflation, a situation that the high unemployment along with low economic growth, also exhibit an irregular relationship between different factors. This is similar to the purpose of this paper: try to jump out of the existing framework and find the potential aspects. This also offers an inspiration that in a future study, a specific term will be coined to explain the irregular relationship between the unemployment rate and wage growth in recessions.

The next thing to mention is some hypotheses to prove in the paper. The first is about the effect of productivity on unemployment, and the second is about the demand on labors.

The two are discussed together because they are slightly related to the second Labour mobility.

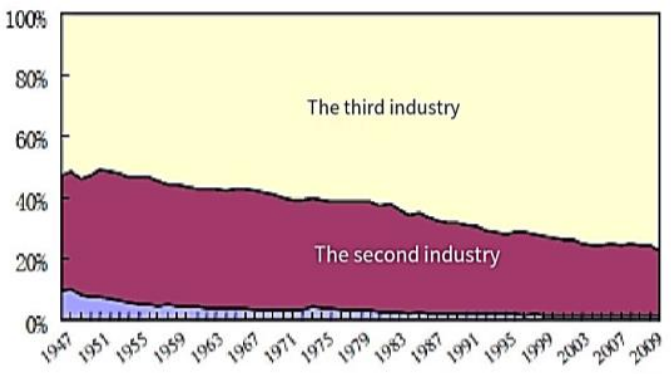

Figure 13 Three major industries in the United States [26]

According to the data, since the Second World War, the proportion of the second industry in THE GDP of the United States has increased by about seventy times. The share of the tertiary industry in GDP has risen from less than 60 percent to about 80 percent[1]. Clark believes that there is a close relationship between industrial structure and labour force employment. The higher the national income per capita, the smaller the share of agricultural labour in the total labour force. This could explain why agriculture has a lower share than the secondary and tertiary industries. Therefore, why is the United States still called an "agricultural power"? First, it involves high-tech industries, helping to mechanize agriculture. Productivity increased, and agriculture flourished. However, with it comes the loss of jobs related to agriculture.

Although the first picture shows the proportion of secondary industry in decline year by year, (seen from the two pictures above), the second industry manufacturing is still the state of the lack of labour force. Besides, one can also see the need of the labour force, most belong to the second, the third industry, the low level of wages in the 
post, information about high pay work labour shortages also temporarily didn't look up to. In addition the primary industry is not too short of labour. Besides, when it comes to labour mobility, of course, where labour is scarce, where labour is in high demand, labour is more likely to move there.

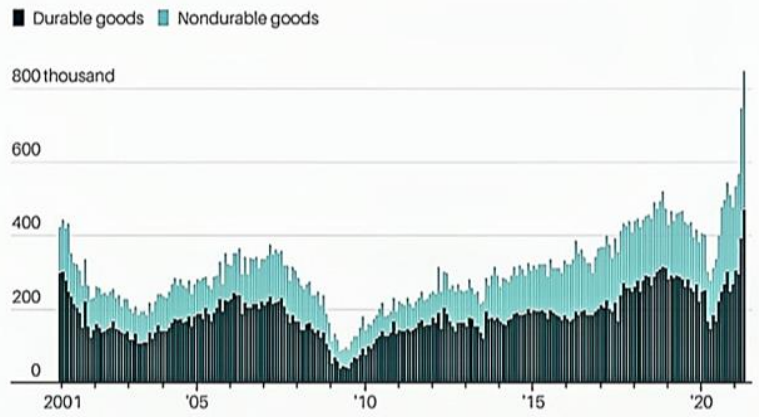

Figure 14 Unfilled American manufacturing jobs [27]

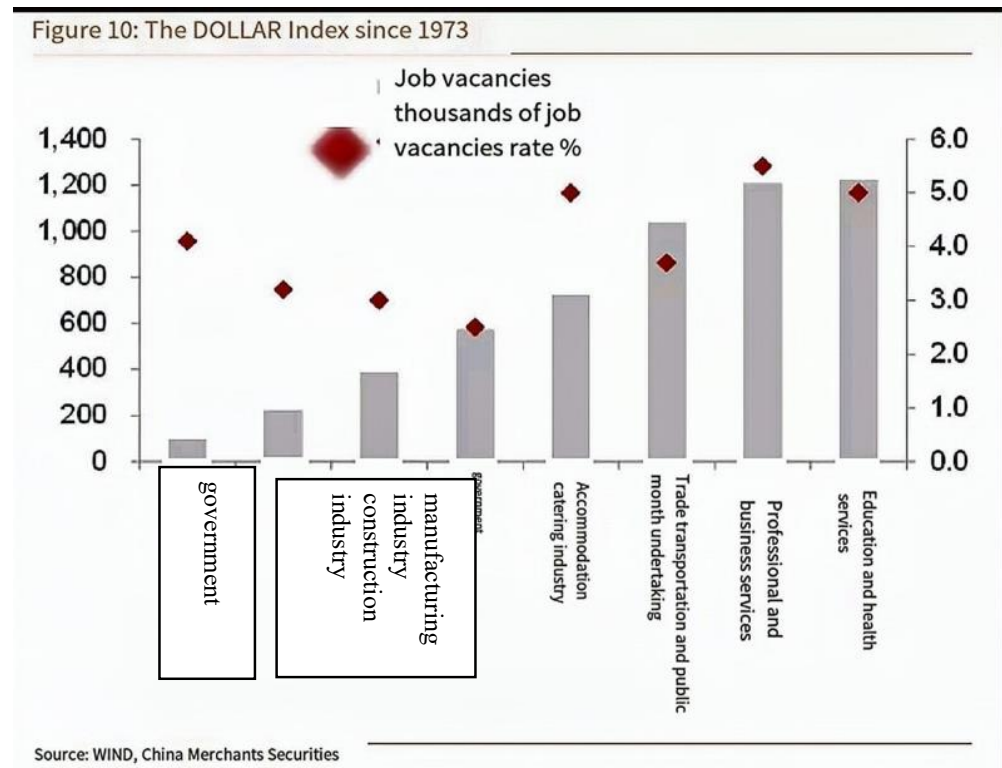

Figure 15The percentage of job openings for different jobs [28]

The third point is about gender differences, thegender wage gap is defined as the difference between median earnings of men and women relative to median earnings of men. It's not just experience and job differences that affect wages, but also gender differences. As shown in the Fig. 16, men earn more than women.

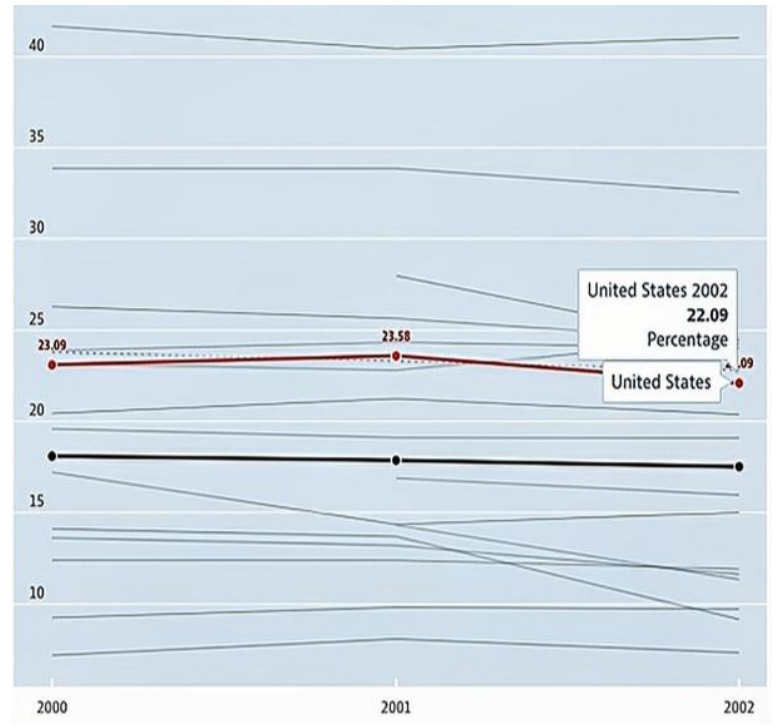

Figure 16 Gender wage gap of employees in 20002002[29]

This paper reviews previous studies and discusses the effects of productivity, gender gap, and labor mobility on 
unemployment in the context of the 2001 recession, and finds that the unemployment rate is influenced by these factors. However, because the points discussed in this paper are influenced by time and country choice, it is not possible to study the economy during World War I and World War II, nor some developing countries, but these aspects are worth further study in the future.

\section{CONCLUSION}

In summary, this paper investigated the relationship between low unemployment and actual wage growth in the U.S. in 2001. This paper used data on the unemployment rate and wage growth in 2001, then drew Phillip's curve in 2001. Comparing with Phillip's curve in 2011, research indicated that reduced unemployment rate did not deliver q prominent increasing trend in wage growth, which fully proved the differences between normal Phillip's curve and those in 2001.

Eventually, this paper found three aspects through data analysis. Firstly, a direct factor of the unusual relationship between unemployment and wage growth was that the replacement of foreign-born labors. Reducing the unemployment rate did not deliver a prominent increasing trend in wage growth in 2001.Secondly, the research showed that the educational level and unemployment rate were inversely related. The educational level and unemployment rate were inversely related. That provided a new aspect in the study of the wage Phillips curve. Finally, the impact of labor element could be subdivided into, degree, different careers, market capacity, work experience, etc. When it comes to these factors change, the unemployment rate will rise or fall. However, it generally will not fluctuate dramatically as there had been a certain development trend.

It partially addressed the issue that why didn't the wage Phillips curve reveal a normal relationship between wage growth and unemployment in 2001 by the three aspects in the previous paragraph. Furthermore, the research provided several new aspects in the study of the wage Phillips curve as well as what led to low wage growth in 2001.

\section{REFERENCES}

[1] History.com Editors. "Marshall Plan." History.com, A\&E Television Networks, 16 Dec. 2009, www.history.com/topics/world-war-ii/marshallplan-

1\#: :text=What $\% 20 \mathrm{Was} \% 20$ the $\% 20 \mathrm{Marshall} \% 20$

Plan\%3F\%20The\%20Marshall\%20Plan\%2C,to\%2 Ohelp\%20finance $\% 20$ rebuilding $\% 20$ efforts $\% 20$ on $\% 20$ the $\% 20$ continent.

[2] United States Unemployment Rate1948-2021 Data: 2022-2023 Forecast: Calendar. United States Unemployment Rate | 1948-2021 Data | 2022-2023 Forecast | Calendar. (n.d.). https://tradingeconomics.com/united-

states/unemployment-rate.

[3] United States wages and Salaries growth1960-2021 Data: 2022-2023 Forecast. United States Wages and Salaries Growth | 1960-2021 Data | 2022-2023 Forecast. (n.d.). https://tradingeconomics.com/united-states/wagegrowth.

[4] Duleep, Harriet Orcutt, and Mark C. Regets. "Measuring Immigrant Wage Growth Using Matched CPS Files." $<\mathrm{i}>$ Demography $</ \mathrm{i}>$, vol. 34, no. 2, 1997, pp. 239-249. <i >JSTOR</i>, www.jstor.org/stable/2061702. Accessed 3 Sept. 2021.

[5] Bronars, Stephen G., and Melissa Famulari. "Wage, Tenure, and Wage Growth Variation within and across Establishments." $<\mathrm{i}>$ Journal of Labor Economics $</ i>$, vol. 15, no. 2, 1997, pp. 285-317. $<\mathrm{i}>\mathrm{JSTOR}</ \mathrm{i}\rangle, \quad$ www.jstor.org/stable/2535391. Accessed 3 Sept. 2021.

[6] Munasinghe, Lalith. "Wage Growth and the Theory of Turnover." $<\mathrm{i}>$ Journal of Labor Economics $</ \mathrm{i}>$, vol. 18, no. 2, 2000, pp. 204-220. <i $>\mathrm{JSTOR}</ \mathrm{i}>$, www.jstor.org/stable/10.1086/209956. Accessed 3 Sept. 2021.

[7] Fatehin, Sohani, and David Sjoquist. "High Wage Job Growth and Tax." $<\mathrm{i}>$ Proceedings. Annual Conference on Taxation and Minutes of the Annual Meeting of the National Tax Association $\langle/ i\rangle$, vol. 109, $2016 . \quad<\mathrm{i}>\mathrm{JSTOR}<\mathrm{i}>$, www.jstor.org/stable/26816606. Accessed 3 Sept. 2021.1

[8] Daly, Mary C., and Bart Hobijn. "Composition and Aggregate Real Wage Growth." $<\mathrm{i}>$ The American Economic Review</i>, vol. 107, no. 5, 2017, pp. 349-352.

$<\mathrm{i}>\mathrm{JSTOR}<\mathrm{i}>$, www.jstor.org/stable/44250419. Accessed 3 Sept. 2021.

[9] Phillips, A. W. "The Relation between Unemployment and the Rate of Change of Money Wage Rates in the United Kingdom, 1861-1957." $<\mathrm{i}>$ Economica $</ \mathrm{i}>$, vol. 25, no. 100, 1958, pp. 283 299. $<\mathrm{i}>$ JSTOR $</ \mathrm{i}>$, www.jstor.org/stable/2550759. Accessed 3 Sept. 2021.

[10] Samuelson, Paul A., and Robert M. Solow. "Analytical Aspects of Anti-Inflation Policy." $<\mathrm{i}>$ The American Economic Review $</ \mathrm{i}>$, vol. 50, no. 2, 1960, pp. 177-194. <i >JSTOR</i>, www.jstor.org/stable/1815021. Accessed 3 Sept. 2021. 
[11] Baidu Baike. https://mbd.baidu.com/ma/s/oa7SEC6a.

[12] Pacific Computer Network. https://mbd.baidu.com/ma/s/o04hRUyM.

[13] Gordon, Robert. "The Phillips Curve Now and Then." 1990, doi:10.3386/w3393.

[14] Friedman, Milton. "The Role of Monetary Policy." $<i>$ The American Economic Review</i $>$, vol. 58, no. 1, 1968, pp. 1-17. <i >JSTOR $<$ i $>$, www.jstor.org/stable/1831652. Accessed 3 Sept. 2021.

[15] Mary C. Daly, Bart Hobijn. "The Path of Wage Growth and Unemployment." Federal Reserve Bank of San Francisco, Federal Reserve Bank of San Francisco, 15 July 2013, www.frbsf.org/economicresearch/publications/economicletter/2013/july/wages-unemployment-rate/.

[16] Phelps, Edmund S. "Money-Wage Dynamics and Labor-Market Equilibrium." $<\mathrm{i}>$ Journal of Political Economy</i>, vol. 76, no. 4, 1968, pp. 678-711. $<\mathrm{i}>$ JSTOR $</ \mathrm{i}>, \quad$ www.jstor.org/stable/1830370. Access ed 3 Sept. 2021.

[17] Migration - foreign-born unemployment - oecd data. theOECD. (n.d.). https://data.oecd.org/migration/foreign-bornunemployment.htm.

[18] Migration - foreign-born population - oecd data. theOECD.

(n.d.). https://data.oecd.org/migration/foreign-bornpopulation.htm\#indicator-chart.

[19] Migration - foreign-born employment - oecd data. theOECD. (n.d.). https://data.oecd.org/migration/foreign-bornemployment.htm\#indicator-chart.

[20] Migration - native-born employment - oecd data. theOECD.

(n.d.). https://data.oecd.org/migration/native-bornemployment.htm\#indicator-chart.

[21] The role of foreign-born workers in the U.S. economy.

(n.d.). https://www.bls.gov/opub/mlr/2002/05/art1full.pdf. tt.byteimg.com/origin/e940006d7f7c959b87c?from $=\mathrm{pc}$

[23] Middle - and low-income population in the United States. (n.d.). https://mz.mbd.baidu.com/r/szS7mS3S7K?f=cp\&a $\mathrm{mp} ; \mathrm{u}=\mathrm{b} 2 \mathrm{c} 3 \mathrm{e} 3 \mathrm{~cd} 4 \mathrm{~b} 735 \mathrm{dc} 8 \% \mathrm{C} 2 \% \mathrm{~A} 0 \% \mathrm{C} 2 \% \mathrm{~A} 0 \% \mathrm{C} 2$ $\% \mathrm{~A} 0 \% \mathrm{C} 2 \% \mathrm{~A} 0 \% \mathrm{C} 2 \% \mathrm{~A} 0 \% \mathrm{C} 2 \% \mathrm{~A} 0 \% \mathrm{C} 2 \% \mathrm{~A} 0 \% \mathrm{C} 2$ $\% \mathrm{~A} 0 \% \mathrm{C} 2 \% \mathrm{~A} 0$.
[24] Earnings and wages - wage levels - oecd data. theOECD. https://data.oecd.org/earnwage/wage-levels.htm.

[25]

https://i0.hdslb.com/bfs/article/e054d28303ed9ddff 63c55f8091695be544faf0e.png

[26] https://viewcache.book118.com/view1/M04/0C/0F/wKh2BV0 BKTaAd-

DSAAKXEqY4OBY77_31965\%7C11812_4c84 101235501ef1a71af7b3cbb2536443990338.png

[27]

https://n.sinaimg.cn/spider2021610/264/w640h424/ 20210610/9590-krhvrxt5676916.png

[28]

http://img.zhitongcaijing.com/image/20170820/150 3212410126694.png

[29] Earnings and wages - gender wage gap - oecd data. theOECD.

(n.d.). https://data.oecd.org/earnwage/gender-wagegap.htm\#indicator-chart. 